
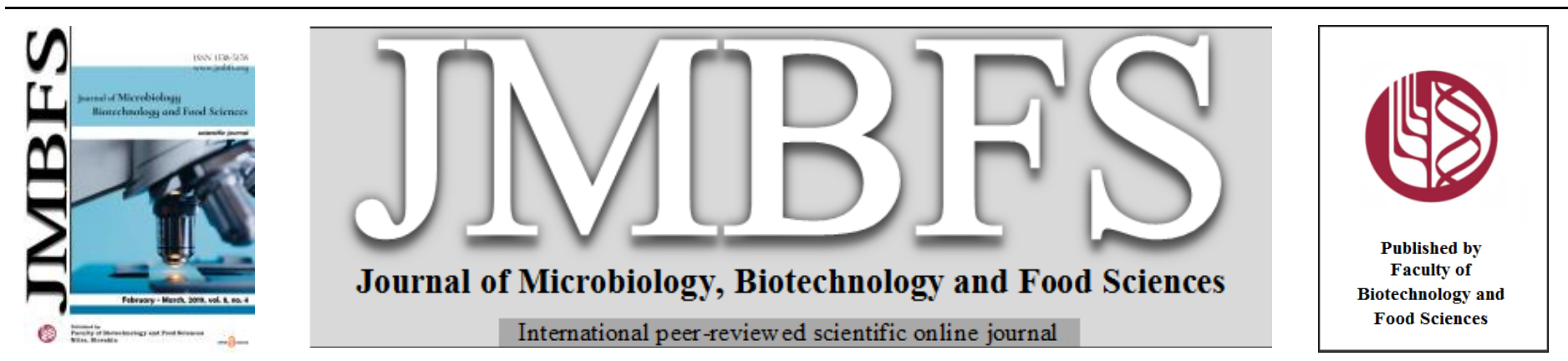

\title{
GELATIN FROM BONES OF BIGHEAD CARP AS A FAT REPLACER ON PHYSICOCHEMICAL AND SENSORY PROPERTIES OF LOW-FAT MAYONNAISE
}

\author{
Mohamed Javad Ataie ${ }^{l}$, Seyed Pezhman Hosseini Shekarabi ${ }^{* 1}$ and Seyed Hassan Jalili ${ }^{2}$
}

\author{
Address(es): \\ ${ }^{1}$ Department of Fisheries Science, Science and Research Branch, Islamic Azad University, Tehran, Iran. \\ ${ }^{2}$ Fish Processing Technology Research Department, Inland Waters Aquaculture Research Center, Iranian Fisheries Research Organization, Agricultural Research, \\ Education and Extention Organization (AREEO), Bandar Anzali, Iran.
}

*Corresponding author: hosseini@srbiau.ac.ir / hosseini.pezhman@yahoo.com

doi: 10.15414/jmbfs.2019.8.4.979-983

\section{ARTICLE INFO}

Received 4. 8. 2018

Revised 5. 10. 2018

Accepted 17. 10. 2018

Published 1. 2. 2019

Regular article

open $\partial_{\text {ACCESS }}$

\section{ABSTRACT}

The objective of this study was to produce a low-fat mayonnaise containing gelatin from bighead carp by-products as a fat replacer. Low-fat mayonnaise samples were made by substituting the oil with fish gelatin at 0\% (T0), 10\% (T10), 25\% (T25), and 40\% (T40). Also, some physiochemical properties and sensory qualities of reduced fat mayonnaises were investigated. T40 had the lowest caloric value while, the lowest whiteness was measured in T40 (46.12\%) compared to the control group $(79.58 \%)(\mathrm{P}<0.05)$. The reduced fat in T40 samples presented high values of texture properties as well as the highest hardness, adhesiveness and resilience $(\mathrm{P}<0.05)$. Also, the highest level of emulsion stability was reached in $\mathrm{T} 40$ treatment $(\mathrm{P}<0.05)$. The highest and the lowest titratable acidity were recorded in T0 $(0.85 \%)$ and T40 $(0.60 \%)$ treatments, respectively. The results of sensory evaluation in term of overall acceptability showed that T40 had the highest score compared to other treatments. This study revealed a good potential usage of the fish gelatin as a fat mimetic in low-fat mayonnaise formulation up to $40 \%$.

Keywords: Bighead carp, Fat replacer, Fish gelatin, Mayonnaise, Texture

\section{INTRODUCTION}

Gelatin is a unique hydrocolloid with a mixture of peptides/proteins and produced by partial hydrolysis of collagen from the skin, bones, and connective tissues (Karim and Bhat, 2009). Recently, worldwide demand for gelatin in a vast range of applications in a food industry, hygienic products, cosmetics, biodegradable packaging and pharmaceutical products (Jellouli et al., 2011) is increased, and its market demand is estimated about 326.000 tons (Wang et al., 2014). In the recent years, interest in using of fish gelatin instead of mammalians sources is highly increased due to some social and religion conflicts (Badii and Howell, 2006) as well as transmission disease prevention (Gómez-Guillén et al., 2009). Meanwhile, by-products obtained from fish processing factories such as fish skin and bone could be considered as a valuable source of producing gelatin. Bighead carp (Hypophthalmichthys nobilis) is one of the commercial freshwater fish species which is the most exploited farm-raised fish in earthen ponds in Iran and Asia. Aquaculture production of bighead carp increased rapidly from 3219 tons in 1978 to 3250000 tons in 2014, representing $39.2 \%$ of the total fish production (FAO, 2016). This fish has a large head compared to the body size, and this is why the fish price gets lower than other cyprinid species e.g. common carp, grass carp and silver carp. There is an opportunity to alter this substantial amount of waste materials to gelatin. In other words, fish waste can be treated and converted to various value-added products with high biological values instead of being discarded and causes potential negative environmental impacts (Mahdabi and Hosseini Shekarabi, 2018). However, no study has been carried out to assess the potential use of fish bones in low-fat mayonnaise and/or other food applications.

Mayonnaise is oil-in-water $(\mathrm{O} / \mathrm{W})$ emulsions and traditionally produced by emulsifying materials like egg yolk and contains salt, vinegar, constancy agents and flavored materials (Mun et al., 2009; Pulingundla et al., 2015). Generally, mayonnaise considered as a high fat and calorie levels due to high amount of oil $(>65 \%$ ) (Su et al., 2010), and leads it unhealthy and weight gaining foodstuff especially by increasing in cholesterols and saturated oils in the consumers (Pulingundla et al., 2015). Therefore, development of defat or reduced fat mayonnaise is one of the most important strategies for investigators to find an appropriate fat mimics (Worrasinchai et al., 2006; Lorenzo et al., 2008; Nikzadeh et al., 2012). Hydrocolloids, particularly maltodextrin (Saavedra-Leos et al., 2015) and modified starches improved rheological properties and viscosity of low-fat food products (Weber et al., 2009). Replacing oils with hydrocolloids in $\mathrm{O} / \mathrm{W}$ emulsions leading to increasing in heat stability (Lorenzo et al., 2008), improving texture and mouth feeling (Pszczola, 1999). The benefits of replacing oil with fish gelatin is antioxidant and antibacterial properties of fish gelatin biopeptide, which prevent bacteria growth during storage period (Triawati et al., 2016).

The most important characteristics of fish gelatin can be classified into two groups: i) properties associated with texturizing, thickening, and water capacity, and ii) properties relevant to emulsion, foam formation, stabilization, adhesion, cohesion, and foam forming capacity. Likewise, use of gelatin as a fat substitute is thought to be related to its ability to simulate and mimic the sensory properties of fats (Badii and Howell, 2006; Karim and Bhat, 2009; Wang et al., 2014). Many researches formulated gelatin from different sources as a stabilizer in meat products during storage (Cheng et al., 2014), producing low-fat yoghourt (Behnia et al., 2013), improving creamy mouth-feel and viscosity of feeling in low-fat ice cream (Lim et al., 2013), low-fat whipped cream (Sajedi et al., 2014), improving textural properties of low-fat mascarpone cheese (Carvalho et al., 2015), and low-fat fat spread (Cheng et al., 2008).

The aim of this study was to evaluate the effects of bighead carp gelatin from the head bones on some physiochemical properties and sensory qualities of low-fat mayonnaise.

\section{MATERIALS AND METHODS}

\section{Extraction of gelatin from bighead carp head bones}

Bighead carp heads were prepared from a local market (Tehran, Iran) and stored at $-20^{\circ} \mathrm{C}$ until used. The bones were allowed to completely thaw at room temperature for $4 \mathrm{~h}$ prior to extraction. Gelatin from fish heads was prepared following the procedure described by Muyonga et al. (2004) with some modifications. Briefly, the thawed bone was first thoroughly cleaned with a knife and rinsed with plenty of water to eliminate muscle tissue and then degreased by soaking in $0.1 \mathrm{~N}$ sodium hydroxide at a ratio (bone-to- $\mathrm{NaOH}$ ) of $1: 1(\mathrm{w} / \mathrm{v})$ at $4^{\circ} \mathrm{C}$ for $4 \mathrm{~h}$ followed by several washing with running tap water until the $\mathrm{pH}$ reached about 6. The degreased bones were then demineralized using $0.4 \mathrm{~N} \mathrm{HCl}$ at ambient temperature for 9 days until the bones became soft and transparent. In this case, the acidulation solution was changed at 3 day intervals. The leached 
bones were washed with running tap water until the wash water $\mathrm{pH}$ was above 4 and reached near 6 . The pretreated materials were transferred to beakers and the gelatin was extracted in water baths (Memmert, Germany) at $70^{\circ} \mathrm{C}$ for $2 \mathrm{~h}$. Afte this stage, the mixture was subjected to a sterilization process by autoclaving at $121{ }^{\circ} \mathrm{C}, 100 \% \mathrm{RH}$ and $1 \mathrm{~atm}$. The extract was filtered through two layers of cheesecloth and dried at $60^{\circ} \mathrm{C}$ for $24 \mathrm{~h}$ in a forced-air oven (Binder, Germany) until the moisture was reached less than $10 \mathrm{~g}$ water per $100 \mathrm{~g}$ of gelatin. The brittle sheets of gelatin were broken into small pieces and milled (IKA Works A11 Basic Mill, Germany) into powder (particle size $1 \mathrm{~mm}, 90 \%$ mesh passed). The dried gelatin powder was stored in air-tight polyethylene bags and kept in a cool and dry place.

\section{Preparation of aqueous phase}

Aqueous phase solution were prepared by dispersing of $10 \mathrm{~g}$ fish gelatin and $2 \mathrm{~g}$ maltodextrin (food grade, DE $<20$, Dalian Future International Co., China) powders in double distilled water with $2 \mathrm{ml}$ skimmed milk (Mihan, Tehran) and stirring for $10 \mathrm{~min}$ at room temperature. The aqueous phase were stored at $4^{\circ} \mathrm{C}$ prior to further usage. Sodium azide (Sigma-Aldrich, UK) at $0.02 \%$ (w/w) was added to the stock solutions to prevent microbial growth (Wu and McClements, 2015)

\section{Preparation of low-fat mayonnaise}

Mayonnaise samples were prepared as described previously by Liu et al. (2007) with some modifications. The recipes of mayonnaise as control and low-fat samples are shown in Table 1. First, egg yolk and vinegar were mixed in a glass beaker and blended using a KitchenAid mixer (K4555, St. Joseph, Michigan, USA) at medium speed for $10 \mathrm{~s}$ in order to provide consistent and reliable samples. Then, prepared aqueous phase was added and stirred at high speed for min. Finally, the sunflower oil was added slowly $(200 \mathrm{~mL} / \mathrm{min}$ flow rate), and all the ingredients were stirred at high speed for $2 \mathrm{~min}$. Mayonnaises were transferred to a plastic sealed jars and protected against light and moisture, then stored at refrigerator $\left(4^{\circ} \mathrm{C}\right)$ over the night until further analysis.

Table 1 Ingredients of full-fat and low-fat mayonnaise samples by fish gelatin from bighead carp bones.

\begin{tabular}{lcccc}
\hline & $\mathrm{T}^{*}$ & $\mathrm{~T}^{*} 0^{* *}$ & $\mathrm{~T}^{*} 5^{* * *}$ & $\mathrm{~T}^{*} 0^{* * * *}$ \\
\hline Sunflower oil & 70 & 63 & 52.5 & 42 \\
Egg yolk & 12 & 12 & 12 & 12 \\
Gelatin (aqueous phase) & 0 & 7 & 17.5 & 28 \\
Vinegar & 12 & 12 & 12 & 12 \\
Mustard & 0.3 & 0.3 & 0.3 & 0.3 \\
Sugar & 0.5 & 0.5 & 0.5 & 0.5 \\
Distilled water & 5.2 & 5.2 & 5.2 & 5.2 \\
\hline * Full-fat mayonnase. & & & &
\end{tabular}

* Full-fat mayonnaise.

fish gelatin in aqueous phase was added).

*** Reduced-fat mayonnaise in which sunflower oil replaced by fish gelatin aqueous phase at the level of $25 \mathrm{wt} \%$ (when $25 \%$ of fish gelatin in aqueous phase was added).

**** Reduced-fat mayonnaise in which sunflower oil replaced by fish gelatin aqueous phase at the level of $40 \mathrm{wt} \%$ (when $40 \mathrm{wt} \%$ of fish gelatin in aqueous phase was added).

\section{Approximate composition and caloric values}

Proximate composition namely, moisture, lipid, ash and protein were determined according to AOAC (2000) method. Also, fat content was measured by Bligh and Dyer (1959) method. Carbohydrate level was determined by subtracting total percent values of moisture, protein, fat, and ash from 100.

The caloric value $(\mathrm{kcal} / 100 \mathrm{~g})$ for each mayonnaise samples was calculated by following formula:

Total calorie value $=($ protein $\times 4.02)+($ Lipid $\times 9)+($ Carbohydrate $\times 3.87)$

\section{Measurement of pH}

The $\mathrm{pH}$ was determined by weighing $5 \mathrm{~g}$ of mayonnaise and homogenizing in 45 $\mathrm{mL}$ distilled water in a mixer (IKA Ultra-Turrax T25 basic homogenizer, Germany) at room temperature $\left(25^{\circ} \mathrm{C}\right)$ for $1 \mathrm{~min}$. The $\mathrm{pH}$ of each slurry was determined with a digital $\mathrm{pH}$ meter (Model 827, Metrohm, Switzerland).

\section{Emulsion stability measurement}

The emulsion stability of mayonnaise was measured following a method of Bortnowska and Makiewicz (2006). Fifteen $g$ (F0) of each sample was transferred to test tubes (internal diameter $15 \mathrm{~mm}$, height $125 \mathrm{~mm}$ ) and then tightly sealed with plastic caps and stored in the oven at $50{ }^{\circ} \mathrm{C}$ for $48 \mathrm{~h}$. Heated samples were centrifuged for $10 \mathrm{~min}$ at $2500 \times \mathrm{rpm}$ to remove the top oil layer. The weight of the precipitated fraction (F1) was measured, and the emulsion stability was calculated as follows:

Emulsion stability $(\%)=\mathrm{F} 1 / \mathrm{F} 0 \times 100$

where $\mathrm{F} 1$ is a precipitated fraction $(\mathrm{g})$ and $\mathrm{F} 0$ is an entire weight $(\mathrm{g})$.

\section{Titratable acidity}

Titratable acidity (TA) was determined by titration of $10 \mathrm{~g}$ mayonnaise to $\mathrm{pH} 8$ with $0.1 \mathrm{~N} \mathrm{NaOH}$ using a digital $\mathrm{pH}$ meter $(827 \mathrm{pH}$ lab, Metrohm, Swiss $)$ at room temperature and results were converted to percentage of acetic acid according to the following formula (Abu-Salem and Abu-Arrab, 2008):

$$
T A(\%)=(0.006 a / b) \times 100
$$

Where $\mathrm{a}$ is the volume of used $\mathrm{NaOH}(\mathrm{ml})$ and $\mathrm{b}$ is the sample weight $(\mathrm{g})$

\section{Color determination}

Mayonnaise samples were measured for color in the $\mathrm{L}^{*}, \mathrm{a}^{*}, \mathrm{~b}^{*}$ system where $(+a)$ is the red, $(-a)$ is the green, $(+b)$ is the yellow, and (-b) is the blue directions using a Hunter lab digital colorimeter (Colorflex EZ, Hunterlab, Virginia, USA). A fixed amount of mayonnaise was poured into the measurement cup and whiteness index was calculated using the following formula (Chaijan and Undeland, 2015):

Whiteness $\left.\%=100-\left[\left(100-L^{* 2}\right)+a^{* 2}+b^{* 2}\right)\right]^{1 / 2}$

\section{Texture profile analysis}

Texture properties of all treatments were evaluated at room temperature using a Texture Analyzer (CT3, Brookfield, USA) equipped with a cylindrical probe (42 $\mathrm{mm}$ diameter). The sample was filled into an acrylic container (42 $\mathrm{mm}$ interna diameter and 55 height) in a depth of $30 \mathrm{~mm}$. The test speed was fixed at 1.00 $\mathrm{mm} / \mathrm{s}$ with a test distance of $15 \mathrm{~mm}$, and upon compression the disc was returned to the initial starting point. From the resulting of force-time curve, firmness ( $\mathrm{g}$ ), resilience, adhesive force $(\mathrm{g})$ and consistency $(\mathrm{g} / \mathrm{s})$ were calculated

\section{Sensory evaluation}

Sensory evaluation of the mayonnaise samples were conducted throughout the one-day refrigerated storage. The sensory panel consisted of 8 expert staff members (four men and four women, ages 26-35) of Razi Complex Laboratory who had been selected according to International Organization for Standardization (ISO) and familiar with hedonic scale method. All sample observations were conducted according to recommendations described in ISO 13299:2003 guidelines. Samples for testing were taken out of the refrigerator and allowed to stand at ambient temperature prior to preparation. About $10 \mathrm{~g}$ of each sample was placed in a polypropylene container which was labeled with a threedigit random number. Also, the sample presentation order was randomized. Four sensory attributes were evaluated (flavor, texture, color and overall palatability) using a 5-point hedonic scale where $5=$ extremely excellent and $1=$ extremely poor.

\section{Statistical analysis}

All physicochemical experiments were replicated three times in a completely randomized factorial design. A one-way analysis of variance (ANOVA) was conducted. When a significant main effect was detected, the means were separated with the post-hoc Tukey's test. The predetermined acceptable level of probability was $5 \%(\mathrm{P}<0.05)$ for all comparisons. The Kruskal-Wallis test was used to find out significant differences for the sensory attributes as a nonparametric analysis of variance at a 5\% level of significance. All analysis was performed using SPSS software (v20.0 for Windows).

\section{RESULTS}

\section{Chemical composition and caloric values}

The approximate composition of dried gelatin powder derived from bighead carp bones are consisted of $95.08 \pm 0.021 \%$ protein, $1.59 \pm 0.014 \%$ lipid and $3.41 \pm 0.014 \%$ ash in dry basis. Also, the chemical composition and caloric values of the low-fat mayonnaise samples are listed in Table 2. There were no significant $(\mathrm{P}>0.05)$ difference between $\mathrm{T} 25$ and $\mathrm{T} 40$ samples in ash content, while carbohydrate content slightly increased with increasing in level of fat substitution. The full-fat mayonnaise $(\mathrm{T} 0)$ had higher $(\mathrm{P}<0.05)$ lipid and caloric contents than the low-fat mayonnaise samples. 
Table 2 Chemical composition and caloric contents of reduced fat mayonnaise samples by fish gelatin from bighead carp bones

\begin{tabular}{lcccccc}
\hline Treatments & Protein $(\%)$ & Lipid $(\%)$ & Moisture $(\%)$ & Ash $(\%)$ & Carbohydrate $(\%)$ & Calorie $(\mathrm{kcal} / 100)$ \\
\hline T0 & $2.38 \pm 0.014^{\mathrm{d}}$ & $77.99 \pm 0.014^{\mathrm{a}}$ & $18.40 \pm 0.014^{\mathrm{d}}$ & $1.23 \pm 0.014^{\mathrm{d}}$ & $1.23 \pm 0.014^{\mathrm{c}}$ & $716 \pm 0.014^{\mathrm{a}}$ \\
T10 & $3.60 \pm 0.014^{\mathrm{c}}$ & $64.63 \pm 0.53^{\mathrm{b}}$ & $29.41 \pm 0.021^{\mathrm{c}}$ & $0.88 \pm 0.014^{\mathrm{c}}$ & $2.37 \pm 0.523^{\mathrm{b}}$ & $605.51 \pm 2.737^{\mathrm{b}}$ \\
T25 & $6.50 \pm 0.014^{\mathrm{b}}$ & $52.5 \pm 0.707^{\mathrm{c}}$ & $36.23 \pm 0.014^{\mathrm{b}}$ & $1.11 \pm 0.084^{\mathrm{b}}$ & $4.77 \pm 0.679^{\mathrm{a}}$ & $517.58 \pm 3.592^{\mathrm{c}}$ \\
T40 & $9.21 \pm 0.269^{\mathrm{a}}$ & $41.50 \pm 0.700^{\mathrm{d}}$ & $44.34 \pm 0.028^{\mathrm{a}}$ & $1.09 \pm 0.094^{\mathrm{b}}$ & $4.95 \pm 0.467^{\mathrm{a}}$ & $430.14 \pm 3.422^{\mathrm{d}}$ \\
\hline Means with different letters in the same column are significantly different (n=3,P<0.05).
\end{tabular}

\section{Total acidity and pH}

The $\mathrm{pH}$ values of the control and low-fat mayonnaises with different the fish gelatin ratios after a day storage at room temperature are shown in Table 3. $\mathrm{pH}$ value significantly reached the maximum value in T40 sample, while no significant different from other trials was seen.

As shown in Table 3, increasing in replacing of the oil with fish gelatin resulted in lower acidity value of the low-fat mayonnaise samples.

Table 3 Changes in $\mathrm{pH}$ and acidity of reduced fat mayonnaise samples by fish gelatin from bighead carp bones

\begin{tabular}{lllll}
\hline & T0 & T10 & T25 & T40 \\
\cline { 2 - 4 } $\mathrm{pH}$ & $3.93 \pm 0.014^{\mathrm{a}}$ & $4.055 \pm 0.021^{\mathrm{a}}$ & $4.14 \pm 0.014^{\mathrm{a}}$ & $4.485 \pm 0.092^{\mathrm{a}}$ \\
Acetic acid $(\%)$ & $0.85 \pm 0.106^{\mathrm{a}}$ & $0.76 \pm 0.061^{\mathrm{b}}$ & $0.71 \pm 0.078^{\mathrm{c}}$ & $0.060 \pm 0.025^{\mathrm{d}}$ \\
\hline Means with different letters in the same row are significantly different $(\mathrm{n}=3, \mathrm{P}<0.05)$. & &
\end{tabular}

\section{Emulsion stability}

Figure 1 illustrates the emulsion stability of control (T0) and low-fat mayonnaise samples. The T10 and T25 samples exhibited the lowest stability and are fairly look like commercial mayonnaises available in the markets, however both control (T0) and T40 trials had the highest emulsion stability with no significant different (Figure 1).

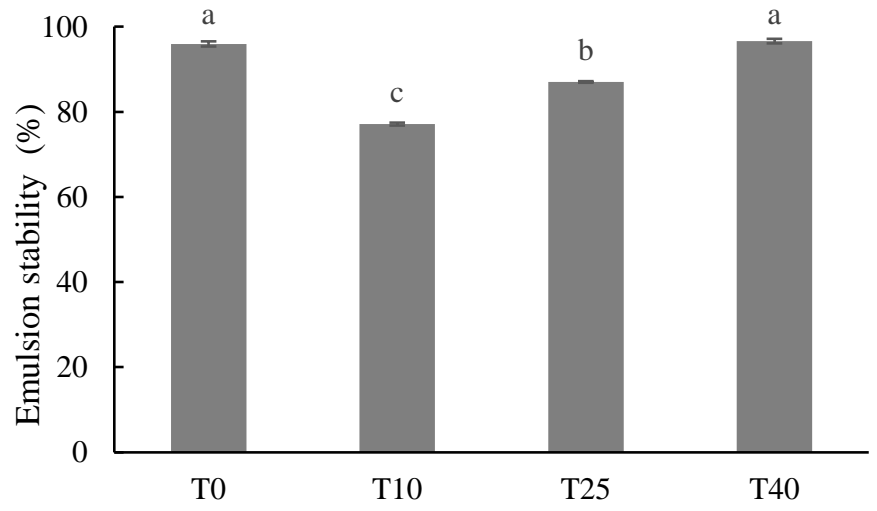

Figure 1 Emulsion stability of reduced fat mayonnaise samples by fish gelatin from bighead carp bones. Full-fat mayonnaise (T0) and low-fat mayonnaises by replacing oil at 10\% (T10); 25\% (T25) and 40\% (T40) by fish gelatin. Bars with the different letters are significantly different $(n=3, P<0.05)$.

\section{Color of mayonnaise}

The color coordinate values of the T0 (control) and low-fat mayonnaise samples with the different fish gelatin at desired rations after storage for one day at the room temperature are shown in Table 4 . The highest $L^{*}$ value was obtained in full-fat sample compared to low-fat samples.

Table 4 Changes of color parameters of reduced fat mayonnaise samples by fish gelatin from bighead carp bones.

\begin{tabular}{lcccc}
\hline Samples & $\mathrm{L}^{*}$ & $\mathrm{a}^{*}$ & $\mathrm{~b}^{*}$ & Whiteness \\
\hline T0 & $87.6 \pm 0.007^{\mathrm{a}}$ & $4.51 \pm 0.028^{\mathrm{b}}$ & $15.59 \pm 0.001^{\mathrm{d}}$ & $79.58 \pm 0.002^{\mathrm{a}}$ \\
T10 & $81.19 \pm 0.092^{\mathrm{b}}$ & $5.85 \pm 0.007^{\mathrm{a}}$ & $20.59 \pm 0.057^{\mathrm{c}}$ & $71.65 \pm 0.018^{\mathrm{b}}$ \\
T25 & $81.77 \pm 0.042^{\mathrm{b}}$ & $4.28 \pm 0.078^{\mathrm{c}}$ & $21.67 \pm 0.028^{\mathrm{b}}$ & $71.36 \pm 0.060^{\mathrm{b}}$ \\
T40 & $80.69 \pm 0.069^{\mathrm{c}}$ & $4.12 \pm 0.014^{\mathrm{d}}$ & $26.05 \pm 0.028^{\mathrm{a}}$ & $67.31 \pm 0.017^{\mathrm{c}}$ \\
\hline
\end{tabular}

\section{Textural properties}

Table 5 shows some texture attributes of the low-fat mayonnaise sample prepared. The low-fat samples had higher textural characterizations in comparison to control ones. The firmness of the low-fat samples increased by increasing in the level of fat substituting and the lowest value was obtained in control ones. Low-fat samples revealed more adhesiveness values, particularly the highest value was observed in T40 (Table 5).

Table 5 Textural properties of reduced fat mayonnaise samples by fish gelatin from bighead carp bones.

\begin{tabular}{lcccc}
\hline Texture & Firmness $(\mathrm{g})$ & Consistency $\mathrm{g} / \mathrm{s})$ & Resilience & Adhesive force $(\mathrm{g})$ \\
\hline T0 & $2412.25 \pm 252.382^{\mathrm{c}}$ & $22.25 \pm 2.623^{\mathrm{c}}$ & $0.74 \pm 0.007^{\mathrm{b}}$ & $99.50 \pm 9.192^{\mathrm{d}}$ \\
T10 & $2064.75 \pm 86.621^{\mathrm{c}}$ & $22.77 \pm 3.111^{\mathrm{c}}$ & $0.74 \pm 0.035^{\mathrm{b}}$ & $173.75 \pm 3.889^{\mathrm{c}}$ \\
T25 & $2700.25 \pm 31.466^{\mathrm{b}}$ & $25.77 \pm 0.742^{\mathrm{b}}$ & $0.77 \pm 0.028^{\mathrm{a}}$ & $281.75 \pm 15.203^{\mathrm{b}}$ \\
T40 & $2958.75 \pm 71.064^{\mathrm{a}}$ & $28.02 \pm 1.697^{\mathrm{a}}$ & $0.78 \pm 0.014^{\mathrm{a}}$ & $313.50 \pm 42.426^{\mathrm{a}}$ \\
\hline Means with different letters in the same column are significantly different $(\mathrm{n}=3, \mathrm{P}<0.05)$.
\end{tabular}

\section{Sensory evaluation}

Sensory evaluation scores of low-fat mayonnaise samples are shown in Table 6 The appearance and odor scores are significantly $(\mathrm{P}<0.05)$ improved with increasing the replacement level of fish gelatin. Color of the T40 sample was evaluated as too faint. On the other hand, the color score were markedly decreased by increasing the fish gelatin replacement levels. T25 and T40 samples showed no significant $(\mathrm{P}>0.05)$ differences in texture scores from the T0 (Fullfat), whereas the T10 sample gave lower score for these attributes.

Table 6 Sensory evaluation of reduced fat mayonnaise samples by fish gelatin from bighead carp bones.

\begin{tabular}{|c|c|c|c|c|c|c|}
\hline Treatments & Appearance & Color & Odor & Texture & Consistency & Total acceptance \\
\hline T0 & $3.22 \pm 0.972^{\mathrm{bc}}$ & $4.67 \pm 0.707^{\mathrm{a}}$ & $3.33 \pm 0.707^{\mathrm{c}}$ & $4.11 \pm 0.782^{\mathrm{a}}$ & $3.56 \pm 0.726^{\mathrm{a}}$ & $3.33 \pm 0.707^{\mathrm{b}}$ \\
\hline T10 & $3.00 \pm 0.816^{\mathrm{c}}$ & $4.30 \pm 0.823^{\mathrm{a}}$ & $3.70 \pm 0.823^{\mathrm{b}}$ & $3.40 \pm 0.516^{\mathrm{b}}$ & $3.40 \pm 0.516^{\mathrm{b}}$ & $3.00 \pm 0.919^{c}$ \\
\hline $\mathrm{T} 25$ & $4.20 \pm 0.632^{\mathrm{b}}$ & $3.40 \pm 0.843^{\mathrm{ab}}$ & $3.40 \pm 0.823^{\mathrm{b}}$ & $3.70 \pm 0.949^{\mathrm{a}}$ & $3.50 \pm 0.850^{\mathrm{a}}$ & $3.80 \pm 0.919^{\mathrm{a}}$ \\
\hline $\mathrm{T} 40$ & $4.40 \pm 0.699^{a}$ & $3.00 \pm 0.816^{\mathrm{b}}$ & $4.50 \pm 0.707^{\mathrm{a}}$ & $4.10 \pm 0.738^{a}$ & $3.90 \pm 0.944^{\mathrm{a}}$ & $4.10 \pm 0.738^{\mathrm{a}}$ \\
\hline
\end{tabular}




\section{DISCUSSION}

In this study, low-fat mayonnaise samples can be stabilized by using fish gelatin as a fat replacer, and the physicochemical properties can be improved. Proper emulsion stability and sensory properties were obtained at $40 \%$ of oil replacement with fish gelatin from bones of bighead carp.

The results showed that the reduction in lipid content could be attributed to the substitution of oil in full-fat mayonnaise with hydrocolloids in low-fat mayonnaise (Akoh, 1998). Also, the fish gelatin in aqueous form enhances texture of the low-fat mayonnaise due to more dense gel structure in $\mathrm{O} / \mathrm{W}$ emulsion. Protein content in full-fat samples were much lower than low-fat samples due to higher content of crude protein of fish gelatin. The caloric values of the low-fat samples were significantly reduced, because fish gelatin is main component of aqueous phase as fat replacer, and maltodextrin in the aqueous phase mixture is non-caloric.

The $\mathrm{pH}$ values in this research showed no significantly differences between fullfat and low-fat samples, however $40 \%$ of oil replacement with fish gelatin sample was significantly more $\mathrm{pH}$, this could be explained by dilution of acetic acid res remaining in the low-fat samples (Worrasinchai et al., 2006; Hathcox et al., 1995). Amin et al. (2014) similarly reported that increasing the level of fat substitution with gums (xanthan and guar gums) in mayonnaise formulations resulted in increases in the $\mathrm{pH}$ values due to dilution of acetic acid in the aqueous phase of the low-fat samples. Raford and Board (1993) and Smittle (1997) suggested that $\mathrm{pH}$ of mayonnaise should be 4.1 or less to maintain product free from microorganism particularly from Salmonella $\mathrm{sp}$. The $\mathrm{pH}$ values in this study was microbiological safety according to the $\mathrm{pH}$ ranged from 3.93 to 4.48 .

Acidity is one the most important quality parameters for assessing spoilage rate of mayonnaise and desired total acidity was reported 0.7-1.2\% acetic acid (Mihov et al., 2012). If the finished product is lower than this range, the risk of microbia growth greatly increase and also resulted in sour taste (Johari et al., 2015). The highest titratable acidy were observed in control sample (T0), whereas the low-fat samples, particularly at $40 \%$ of oil replacement with fish gelatin had the lowest acidity index. The reason of increasing in titratable acidity is probably nonenzymatic oxidation (Gomez et al., 2016) and greater acidity value was observed in control samples, which indicated the beginning of lipids decomposition and formation of free fatty acids (Silva et al., 2010). In agreement with the results, Abou-Zeid et al. (2013) reported that full-fat mayonnaise had a significantly higher acidity value than low-fat samples. Increasing in titratable acidity value could be mostly related to activity of acid tolerant microorganisms such as LABs (lactic acid bacteria) due to their hydrolytic and oxidative enzymes activities.

Emulsion stability characteristic of a mayonnaise is highly depend on oil and egg yolk concentration, mixing technique, and temperature (Harrison and Cunningham, 1985; Song et al., 2007). In this study, increasing in fish gelatin concentration caused the emulsion stability more stable. $\mathrm{O} / \mathrm{W}$ emulsion stability of low-fat mayonnaises might be adversely affected by creaminess, flocculation, coagulation and phase diversion due to low content of oil in the formulation (Mun et al., 2009). For instance, in full-fat mayonnaise creaminess is not typically observed, because the oil droplets in these systems are enough close together. Therefore, when the fat level is decreased in mayonnaise, a thickener agent should be added to aqueous phase to reduce creaminess. In this case, replacement of oil with gelatin in low-fat mayonnaise can act as an emulsifier agents in improving of the viscosity features and become more stable due to decrease falling oil droplet movements (Manoj et al., 1998; Manoj et al., 2000). In this research we demonstrated that the reduction of emulsion stability with decreasing in gelatin content probably due to weakening in three-dimensiona network structure (McClements, 2006). Also, fish gelatin and maltodextrin might be tighten the three-dimensional network of emulsion due to ordered construction of molecules but in full-fat sample only egg yolk was used as an emulsifier agent. Mun et al. (2009) similarly reported that emulsion stability of manufactured fullfat and supplemented xanthan gum mayonnaise samples were more than $4 \alpha$ GTase-treated starch sample.

The result showed that full-fat mayonnaise had the highest brightness ( $\left.\mathrm{L}^{*}\right)$. This can be explained that lower emulsion droplet size in the full-fat sample probably decreased scattering of light in comparison to low-fat samples (Chantrapornchai et al., 1999). However, the yellowness value of low-fat mayonnaise increased, as expected with increasing in fish gelatin due to increase of $\beta$-carotene content Canthaxanthin or $\beta$-carotene can reduce color saturation and brightness. Krinsky and Johnson (2005) similarly reported that the yellowness of low-fat mayonnaise samples was higher than full in fat samples. Some investigators reported adverse effects of hydrocolloids when they play a role as a fat substitutes in the color of low-fat mayonnaise (Worrasinchai et al., 2006). However, the results were not in agreement with $\mathrm{Su}$ et al. (2010) reports that revealed when mayonnaise fat replaced with Xanthan gum, citrus fiber and guar gum the brightness value was improved compared to the full fat sample. Hence, Mun et al. (2009) reported that increasing in Xanthan gum and Starch in the emulsion formulation would increase $\mathrm{L}^{*}$ value, that is not in agreement with our findings.

Increasing in hardness in low-fat samples containing fish gelatin could be possibly due to slow post-crystallization process and development of fat crysta networks which are resulted in condensed structure of T40 sample and consequently more force was desired to breaking down the structure (Alexa et al.,
2011). A relationship between our results and Worrasinchai et al. (2006) report are notable. Therefore an increasing in hardness in low-fat products could be due to emulsion structure changed and maintain mono-dispersed condition instead of poly-dispersed state of O/W emulsions. Also, Liu et al. (2007) reported that the properties of low-fat mayonnaise reduced at level of $50 \%$ (cheese water, pectin, and methoxyl) are not noticeably influenced by aqueous phase. Depree and Savage (2001) and Gómez-Guillén et al. (2009) also found that the texture of $\mathrm{O} / \mathrm{W}$ emulsions was significantly affected by viscosity of aqueous phase due to functional groups of hydrophilic and hydrophobic molecules of fish gelatin, especially cold water species gelatin, probably increasing in fish gelatin reduced emulsion oil index and keep it more endure. Fish gelatin may amend the spreadibility and reduce the free water to bound water normally due to the large amount of water incorporated (Williams et al., 2006). Therefore, sticky and viscous values of the low-fat samples were increased.

The texture features was correlated with the data derived from texture analyzer given. Total acceptance scores of T25 and T40 samples were higher than T0 (control) sample. This could be due to rougher differences in aroma, firmness or appearance parameters in the low fat samples compared to full-fat sample. Su et al. (2010) similarly reported that overall acceptability for reduced-fat mayonnaises that was markedly better could be due to changes in starch/gum ratio replacement, which turn consequence on gelling process of starch/gum mixed systems. According to Worrasinchai et al. (2006), the appearance score was significantly decreased in low-fat mayonnaises with more than $50 \%$ substitution of fat by $\beta$-glucan due to poor flavor release characteristics. Stern et al. (2001) also demonstrated the similar sensory characteristic of low-fat mayonnaise at $50 \%$ fat replacement with $\beta$-glucan. It can be concluded that the proper replacement level of fat by different hydrocolloids in mayonnaise is probably below $50 \%$ to maintain sensory properties, thereby in this study fish gelatin was substituted by fat up to $40 \%$ to create a smooth and creamy texture low-fat product. In this study the overall acceptability scores of a commercia mayonnaise (Tabarok Food Industry, Mashhad, Iran) evaluated with the same sensory panel were ranged from 3.50 to 4.80 (data not shown). Therefore, sensory scores higher than 3.50 are considered acceptable when compared with the T0 sample. Thus, T40 sample with replacement level of fish gelatin with oil up to $40 \%$ were judged to be sensorially accepted due to break down easily and give good flavor release in the mouth.

\section{CONCLUSION}

We should consider that fish gelatin can be gratefully used to produce low-fat as well as low-caloric mayonnaise. This finding also suggested that fish gelatin from bones of bighead carp is applicable to produce low-fat $\mathrm{O} / \mathrm{W}$ emulsion food systems. However, in order to confirm the obtained data, it would be desirable to test rheological properties of the low-fat mayonnaise.

Conflict of interest: Authors declare that there is no conflict of interest.

Acknowledgement: The authors greatly appreciate the technical assistance offered by Zakariaye Razi Laboratory Complex staffs.

\section{REFERENCES}

Abou-Zaid, A. A., Abdelhafez, A., \& Amer, M. M. (2013). Effect of basil leaves extracted juice addition on mayonnaise and cake oxidative stability and their sensory characteristics. International Journal of Science and Research, 4(2), 1011-1017.

Abu-Salem, F. M., \& Abu-Arrab, A. A. (2008). Chemical, Microbiological and sensory evaluation of mayonnaise preparation from ostrich eggs. Grasas y Aceites, 59(4), 352-360. https://doi.org/10.3989/gya.2008.v59.i4.529

Akoh, C. C. (1998). Fat replacers. Journal of Food Technology, 52(3), 47-53.

Alexa, R. I., Mounsey, J. S., O’Kennedy, B. T., \& Jacquier, J. C. (2011) Oxidative stability of water/oil mixtures as influenced by the addition of free $\mathrm{Cu}^{2+}$ or $\mathrm{Cu}-$ alginate gel beads. Food Chemistry, 129(2), 253-258 https://doi.org/10.1016/j.foodchem.2011.04.028

Amin, M. H. H, Elbeltagy, A. E., Mustafa, M., \& Khalil, A. H. (2014). Development of low-fat mayonnaise containing different types and level of hydrocolloid gum. Journal of Agroalimentary Processes and Technologies, 20(1), 54-63.

AOAC (2000). Approved methods of the American Association of Cereal Chemists. 17th Edition, American Association of Cereal Chemists, Inc., USA.

Badii, F., \& Howell, N. K. (2006). Fish gelatin: structure, gelling properties and interaction with egg albumen proteins. Food Hydrocolloids, 20(5), 630-640 https://doi.org/10.1016/j.foodhyd.2005.06.006

Behnia, A., Karazhiyan, H., Nizmand, R., \& Mohammadi Nafchi, A. R. (2013) Rheological properties of low fat yogurt containing Cress seed gum. Agricultural Sciences, 4(9), 29-32. http://dx.doi.org/10.4236/as.2013.49B005

Bligh, E. G., \& Dyer, W. J. (1959). A rapid method of total lipid extraction and purification. Canadian Journal of Biochemistry and Physiology, 37(8), 911-917. 
Bortnowska, G., \& Makiewicz, A. (2006). Technological utility of guar gum and xanthan for the production of low fat inulin-enriched mayonnaise. ACTA Scientiarum Polonorum Technologia Alimentaria, 5(2), 135-146.

Carvalho, T., Sousa, S. C., Perez-Martin, R. I., Vazquez, J. A., Carvalho, A. P., \& Gomes, A. M. (2015). Physical and chemical characterization of mascarpone cheese with fish gelatin as a fat substitute. $3^{\text {rd }}$ international conference of Wastes: solutions, treatments and opportunities. Viana do Castelo, Portugal, pp. 103-105. Chaijan, M., \& Undeland, I. (2015). Development of a new method for determination of total index protein in fish muscle. Food Chemistry, 173, 1133 1141. https://doi.org/10.1016/j.foodchem.2014.11.010

Chantrapornchai, W., Clydesdale, F., \& McClements, D. J. (1999). Influence of droplet characteristics on the optical properties of colored oil-in-water emulsions. Colloids and Surfaces A: Physicochemical and Engineering Aspects, 155(2-3), 373-382. https://doi.org/10.1016/S0927-7757(99)00004-7

Cheng, L. H., Lim, B. L., Chow, K. H., Chong, S. M., \& Chang, Y. C. (2008) Using fish gelatin and pectin to make a low-fat spread. Food Hydrocolloids, 22(8), 1637-1640. https://doi.org/10.1016/j.foodhyd.2007.10.006

Cheng, S. E., Pindi, W., Kang, O. L., Abdullah, A., \& Babji, A. (2014). Chicken sausage formulated with gelatin from different sources: A comparison of sensory acceptability and storage stability. World Applied Sciences Journal, 31(12), 2062-2067. https://doi.org/10.5829/idosi.wasj.2014.31.12.658

Depree, J. A., \& Savage, G. P. (2001). Physical and flavor stability of mayonnaise. Trends in Food Science and Technology, 12(5-6), 157-163. https://doi.org/10.1016/S0924-2244(01)00079-6

FAO (2016). Fisheries and aquaculture information and statistics service year book. Food and Agriculture Organization of the United Nations (FAO), Rome, Italy.

Gomez, I. A., Lindenblatt, C. T., Masson, L. M. P., dos Santos-Gomez, F., Freitas-Silva, O., \& da Silva, J. P. L. (2016). Effect of oregano essential oil on oxidative stability of low-acid mayonnaise. IOSR Journal of Pharmacy, 6(11), $45-52$

Gómez-Guillén, M. C., Pérez-Mateos, M., Gómez-Estaca, J., López-Caballero, E., Giménez, B., \& Montero, P. (2009). Fish gelatin: a renewable material for developing active biodegradable films. Trends in Food Science and Technology, 20(1), 3-16. https://doi.org/10.1016/j.tifs.2008.10.002

Harrison, L. J., \& Cunningham, F. E. (1985). Factors influencing the quality of mayonnaise. Journal of Food Quality, 8(1), 1-20.

Hathcox, A. K., Beuchat, L. R., \& Doyle, M. P. (1995). Death of enterohemorrhagic Escherichia coli O157: $\mathrm{H} 7$ in real mayonnaise and reduced calorie mayonnaise dressing as influenced by initial population and storage temperature. Applied and Environmental Microbiology, 61(12), 4172-4177.

Jellouli, K., Balti, R., Bougatef, A., Hmidet, N., Barkia, A., \& Nasri, M. (2011) Chemical composition and characteristics of skin gelatin from grey triggerfish (Balistes capriscus). LWT - Food Science and Technology, 44(9), 1965-1970. https://doi.org/10.1016/i.lwt.2011.05.005

Johari, N., Fahimdanesh, M., \& Garavand, F. (2015). Effect of basil seed gum and tracaganth gum as fat replacers on physiochemical, antioxidant and sensory properties of low-fat mayonnaise. International Journal of Science and Engineering Investigations, 4(1), 51-57.

Karim, A. A., \& Bhat, R. (2009). Fish gelatin: properties, challenges, and prospects as an alternative to mammalian gelatins. Food Hydrocolloids, 23(3), 563-576. https://doi.org/10.1016/j.foodhyd.2008.07.002

Krinsky, N. I., \& Johnson, E. J. (2005). Carotenoid actions and their relation to health and disease. Molecular Aspects of Medicine, 26(6), 459-516. https://doi.org/10.1016/j.mam.2005.10.001

Lim, J., Inglett, G. E., \& Lee, S. (2010). Response to consumer demand for reduced-fat, multi-function al fat replacer. Japan Journal of Food Engineering, 11(4), 163-168. https://doi.org/10.11301/jsfe.11.147

Lin, C. H., Yeh, S. H., Lu, H. Y., \& Gean, P. W. (2003). The similarities and diversities of signal pathways leading to consolidation of conditioning and consolidation of extinction of fear memory. Journal of Neuroscience, 23(23), 8310-8317. https://doi.org/10.1523/JNEUROSCI.23-23-08310.2003

Liu, H., Xu, X. M., \& Guo, S. D. (2007). Rheological, texture and sensory properties of low-fat mayonnaise with different fat mimetics. LWT Food Science and Technology, 40(6), 946-954. https://doi.org/10.1016/j.lwt.2006.11.007

Lorenzo, G., Zaritzky, N., \& Califano, A. (2008). Modeling rheological properties of low-in-fat o/w emulsions stabilized with xanthan/guar mixtures. Food Research International, 41(5), 487-494. https://doi.org/10.1016/j.foodres.2008.02.005

Mahdabi, M., \& Hosseini Shekarabi, S. P. (2018). A comparative study on some functional and antioxidant properties of Kilka meat, fishmeal, and stickwater protein hydrolysates. Journal of Aquatic Food Product Technology, 27(7), 844 858. https://doi.org/10.1080/10498850.2018.1500503

Manoj, P., Fillery-Travis, A. J., Watson, A. D., Hibberd, D. J., \& Robins, M. M (2000). Characterization of a polydisperse depletion-flocculated emulsion: III. Oscillatory rheological measurements. Journal of Colloid and Interface Science, 228(2), 200-206. https://doi.org/10.1006/jcis.2000.6936

Manoj, P., Fillery-Travis, A. J., Watson, A. D., Hibberd, D.J., \& Robins, M. M. (1998). Creaming Behavior. Journal of Colloid and Interface Science, 207(2), 283-293.
McClements, D. J. (2006). Non-covalent interactions between proteins and polysaccharides. Biotechnology Advances, 24: 621-625.

Mihov, R., Nikovska, K., Nenov, N., \& Slavchev, A. (2012). Evaluation of mayonnaise-like food emulsions with extracts of herbs and spices. Emirates Journal of Food and Agriculture, 24(6), 191-199. https://doi.org/10.1016/j.biotechadv.2006.07.003

Mun, S., Kim, Y. L., Kang, C. G., Park, K. H., Shim, Y. J., \& Kim, Y. R. (2009) Development of reduced fat mayonnaise using 4óGtase-modified rice starch and xanthan gum. International Journal of Biological Macromolecules, 44(5), 400 407. https://doi.org/10.1016/j.ijbiomac.2009.02.008

Muyonga, J. H., Cole, C. G., \& Douda, K. G. (2004). Extraction and physicchemical characterization of Nile perch (Lates niloticus) skin and bone gelatin Food Hydrocolloids, https://doi.org/10.1016/j.foodhyd.2003.08.009

Nikzadeh, V., Mazaheri-Tehrani, M., Saadatmand Tarzjan, M. (2012). Optimization of low-cholesterol-low-fat mayonnaise formulation: effect of using soy milk and some stabilizer by mixture design approach. Food Hydrocolloids, 28(2), 344-352. https://doi.org/10.1016/j.foodhyd.2011.12.023

Pszczola, D. E. (1999). Starches and gums move beyond fat replacement. Food Technology, 53(8), 44-80.

Pulingundla, P., Cho, Y. H., \& Lee, Y. T. (2015). Physiochemical and sensory properties of fat reduced mayonnaise formulations prepared with rice starch and starch gum mixtures. Emirates Journal of Food and Agriculture, 27(2), 436-468. https://doi.org/10.1016/j.foodhyd.2011.12.023

Radford, S. A., \& Board, R. G. (1993). Review: fate of pathogens in home-made mayonnaise and related products. Food Microbiology, 10(4), 269-278. https://doi.org/10.1006/fmic.1993.1031

Saavedra-Leos, Z., Leyva-Porras, C., Araujo-Diaz, S. B., Toxqyi-Teran, A., \& Baorras-Enriquez, A. J. (2015). Technological application of maltodextrin according to the degree of polymerization. Molecules, 20(12), 21067-21081. https://doi.org/10.3390/molecules201219746

Sajedi, M., Nasirpour, A., Keramat, J., \& Desobry, S. (2014). Effect of modified whey protein concentrate on physical properties and stability of whipped cream. Food Hydrocolloids, 36, 93-101. https://doi.org/10.1016/j.foodhyd.2013.09.007 Silva, L., Pinto, J., Carrola, J., \& Paiva-Martins, F. (2010). Oxidative stability of olive oil after food processing and comparison with other vegetable oils. Food Chemistry, 121(4), 1177-1187. https://doi.org/10.1016/j.foodchem.2010.02.001 Smittle, R. B. (1977). Microbiology of mayonnaise and salad dressing: a review. Food Protect, 40(6), 415-422. https://doi.org/10.4315/0362-028X$\underline{40.6 .415}$

Song, H., Zhang, S. F., Ma, X. C., Wang, D. Z., \& Yang, J. Z. (2007). Synthesis and application of starch-graft-poly AM-co-AMPS by using a complex initiation system of CS-APS. Carbohydrate Polymers, 69(1), 189-195. https://doi.org/10.1016/j.carbpol.2006.09.022

Stern, P., Valentova, H., \& Pokorny, J. (2001). Rheological properties and sensory texture of mayonnaise. European Journal of Lipid Science and Technology, 103(1), 23-28. https://doi.org/10.1002/1438 9312(200101)103:1<23::AID-EJLT23>3.0.CO;2-P

Su, H. P., Lien, C. P., Lee, T. A., \& Ho, J. H. (2010). Development of low-fat mayonnaise containing polysaccharide gums as functional ingredients. Journal of the Science of Food and Agriculture, 90(5), 806-812. https://doi.org/10.1002/jsfa.3888

Triawati, N. W., Radiati, L. E., Thohari, I., \& Manab, A. (2016). Microbiological and physicochemical properties of mayonnaise using biopolymer of wheygelatin-chitosan during storage. International Journal of Current Microbiology and Applied Sciences, 5(7), 191-199. http://dx.doi.org/10.20546/ijcmas.2016.507.019

Wang, C., Chang, T., Shi, L., Yang, H., Cui, M., \& Tambalu, L. (2014). Seafood processing by-products: collagen and gelatin. In: Kim, SK. (eds) Seafood Processing By-Products. Springer Press, New York, pp. 207-242.

Weber, P., Steinhard, H., \& Pascke, A. (2009). Competitive indirect ELISA for the determination of parvalbumins from various fish species in food grade fish gelatin and Isin-Glass with PARV-19 anti-Parvalbumin antibodies. Agricultural and Food Chemistry, 57(23), 11328-11334. http://dx.doi.org/10.1021/jf902470e Williams, P. A., Phillips, G. O., \& Dickinson, E. (2006). Effect of hydrocolloids on emulsion stability. In: Williams, P, Phillips, GO. (eds) Gums and stabilisers for the food industry. Royal Society of Chemistry, UK, pp. 394-404.

Worrasinchai, S., Suphantharika, M., Pinjai, S., \& Jamong, P. (2006). ß-Glucan prepared from spent brewer's yeast as a fat replacer in mayonnaise. Food Hydrocolloids, 20(1), 68-78. https://doi.org/10.1016/i.foodhyd.2005.03.005

Wu, B. C., \& McClements, D. J. (2015). Microgels formed by electrostatic complexation of gelatin and OSA starch: Potential fat or starch mimetics. Food Hydrocolloids, 47, 87-93. https://doi.org/10.1016/j.foodhyd.2015.01.021 